\title{
МОДИФИКАЦИЯ КОМПОНЕНТОВ РЕЦЕПТУРНОГО СОСТАВА ХЛЕБОБУЛОЧНЫХ ИЗДЕЛИЙ С ПРИМЕНЕНИЕМ ТЕКСТУРИРОВАННЫХ СМЕСЕЙ
}

\author{
M.A. Yanova, N.V. Prisukhina, E.V. Melnikova
}

\section{THE COMPONENTS MODIFICATION OF THE OF RECIPE COMPOSITION OF BAKERY PRODUCTS USING TEXTURED MIXTURES}

\begin{abstract}
Янова Марина Анатольевна - канд. с.-х. наук, доц. каф. товароведения и управления качеством продукции АПК Красноярского государственного аграрного университета, г. Красноярск.

E-mail: yanova.m@mail.ru
\end{abstract}

Присухина Наталья Викторовна - канд. техн. наук, доц. каф. технологий хлебопекарного, кондитерского и макаронного производств Красноярского государственного аграрного университета, г. Красноярск. E-mail: nat3701@mail.ru

Мельникова Екатерина Валерьевна - канд. техн. наук, доц. каф. технологий хлебопекарного, кондитерского и макаронного производств Красноярского государственного аграрного университета, г. Красноярск. E-mail: mev131981@mail.ru

Факторы неблагоприятной экологической ситуации в первую очередь оказывают влияние на здоровье населения. Для защиты от неблагоприятных условий окружающей среды актуальным является создание качественных и безопасных продуктов питания, способных снизить или предотвратить их негативное воздействие. Здоровье людей и частично их эмоииональное состояние зависят от компонентного и качественного состава употребляемых продуктов питания. Ежедневно в суточньй рацион каждого человека должны быть включены хлебобулочные изделия в количестве от 200 до 350 грамм исходя из рекомендаций Института питания РАМН. Производители и научное сообщество, занимающееся работой в области разработки продуктов питания из растительного сырья, находятся в постоянном поиске оптимального решения в производстве качественного продукта для каждого человека. Использование смесей муки пшеничной высшего сорта и текстуратов ячменя или овса в производстве булочных изделий повышает качество
Yanova Marina Anatolyevna - Cand. Agr. Sci., Assoc. Prof., Chair of Merchandizing and Product Quality Control of AIC, Krasnoyarsk State Agrarian University, Krasnoyarsk.

E-mail: yanova.m@mail.ru

Prisukhina Natalya Victorovna - Cand. Techn. Sci., Assoc. Prof., Chair of Technologies of Baking, Confectionery and Macaroni Productions, Krasnoyarsk State Agrarian University, Krasnoyarsk.

E-mail: nat3701@mail.ru

Melnikova Ekaterina Valeryevna - Cand. Techn. Sci., Assoc. Prof., Chair of Technologies of Baking, Confectionery and Macaroni Productions, Krasnoyarsk State Agrarian University, Krasnoyarsk.

E-mail: mev131981@mail.ru

изделий и снижает содержание глютена. В лаборатории Института пищевых производств ФГБОУ ВО Красноярский ГАУ изготовлены 12 испытуемых образцов, два из которых контрольные (без текстуратов), и проведена их органолептическая оценка, в ходе которой оценивались такие показатели качества хлеба, как вкус, аромат, фоорма, ивет и внешний вид. Для изучения влияния текстуратов на качество готовых изделий в работе представлены результаты ффизико-химического анализа булки русской круглой: контроль и смеси муки пшеничной высшего сорта и текстуратов ячменя или овса в соотношении (95/5, 90/10, 85/15, 80/20, 75/25). В ходе исследований по изучению модификации компонентов рецептурного состава выявлено, что лучшие результаты качественных характеристик были у булки русской круглой, произведенной по рещептуре $c$ использованием смеси пшеничной муки высшего сорта и текстурата ячменя в соотношении 85/15 и смеси с использованием текстурата овса в соотношении 85/15. 
Ключевые слова: текстурат, булки, качество булочных изделий, показатели качества, органолептическая оценка.

The factors of unfavorable environmental situation primarily have an impact on the health of the population. In order to protect against adverse environmental conditions it is important to create qualitative and safe food products reducing or preventing their negative impact. People's health and partly their emotional state depend on the component and qualitative structure of consumed food. Bakery products in the amount of 200 to 350 grams should be included in a daily diet of each person, basing on the recommendations of Nutrition Institute RAMS. The producers and scientific community working in the field of nutrition development of food from vegetable raw materials are in continuous search of optimum decision in making qualitative product for each person. Using mixes of premium grade wheat flour and texturate of barley or oats in the production of bakery products increases the quality of the products and reduces the content of gluten. In the laboratory of the Institute of Food Productions FSBEI Krasnoyarsk SAU 12 test samples were produced, two of which were control (without texturate) and their organoleptic assessment was carried out, during which such indicators of bread quality as taste, aroma, shape, color and appearance were evaluated. For studying the influence of texturate on the quality of finished products results of physical and chemical analysis of Russian round bun were presented in the study: control and mixes of premium grade wheat flour and the texturate of barley or oats in the ratio $(95 / 5,90 / 10$, $85 / 15,80 / 20,75 / 25)$. During the researches on studying the modification of the components of prescription structure it was revealed that Russian round bun, made on the compounding with using the mix of premium grade wheat flour and the texturate of barley had the best results of qualitative characteristics in the ratio $85 / 15$ and mixes with using of texturate of oats in the ratio 85/15.

Keywords: texturate, buns, quality of bakery products, quality indicators, organoleptic evaluation.

Введение. Город Красноярск является крупным промышленным центром Красноярского края. Работающие промышленные предприятия с вредными производствами загрязняют окру- жающую среду. Факторы неблагоприятной экологической ситуации в первую очередь оказывают влияние на здоровье населения. Для защиты от неблагоприятных условий окружающей среды актуальным является создание качественных и безопасных продуктов питания, способных снизить или предотвратить их негативное воздействие [1].

Перспективным направлением является введение натуральных добавок в хлебобулочные изделия, поскольку они являются продуктом первой необходимости и пользуются спросом у всех социальных слоев населения [2, 3].

Зерно пшеницы и ржи является основным сырьем для производства муки, используемой в традиционных технологиях хлебопечения. Для расширения ассортимента в мучном производстве перспективным направлением стало создание композиционных мучных смесей из ячменя и овса. К таким можно отнести мучные смеси с зерновыми текстурированными продуктами.

Текстурированная мука получается в результате кратковременной высокотемпературной обработки зерна под давлением (процесс экструзии). Натуральные текстураты имеют большое значение для производства хлебобулочных изделий, так как обладают высокими технологическими свойствами, имеют оптимальные показатели водосвязывающей и жиросвязывающей способности. При использовании экструзионной обработки сырья происходят глубокие биохимические изменения основных питательных веществ - углеводов, клетчатки, белков, что играет значительную роль в повышении функциональности и усвояемости готовых продуктов, следовательно, изучение модификации компонентов рецептурного состава хлебобулочных изделий является актуальной задачей [3-5].

Цель работы. Исследование модификации компонентов рецептурного состава булочных изделий с применением текстурированных смесей из зерновых культур.

Задачи исследования: изучить влияние различных дозировок текстурированных смесей на качество булочных изделий; разработка рецептуры булочки с использованием текстурированной смеси.

Объекты и методы исследования. Объект исследования - булка русская круглая на основе текстурированных смесей. В качестве кон- 
трольного образца использовалась унифицированная рецептура булки русской круглой. При изучении модификации компонентов рецептурного состава булки русской круглой в работе использовали текстурированные смеси, состоящие из пшеничной муки высшего сорта и текстурированного ячменя в соотношении: 95/5, 90/10, 85/15, 80/20, 75/25, и смесь из пшеничной муки высшего сорта и текстурированного овса в соотношении: 95/5, 90/10, 85/15, 80/20, 75/25.
Для изучения качества готовых изделий использовали традиционные методы исследования. Органолептические показатели - по ГОСТ 566765, кислотность - по ГОСТ 5670-96, пористость по ГОСТ 5669-96, влажность - по ГОСТ 21094-75 и ГОСТ 27844-88 «Изделия булочные» [6].

Результаты исследования и их обсуждение. Технологический процесс производства булки русской круглой представлен на рисунке 1.

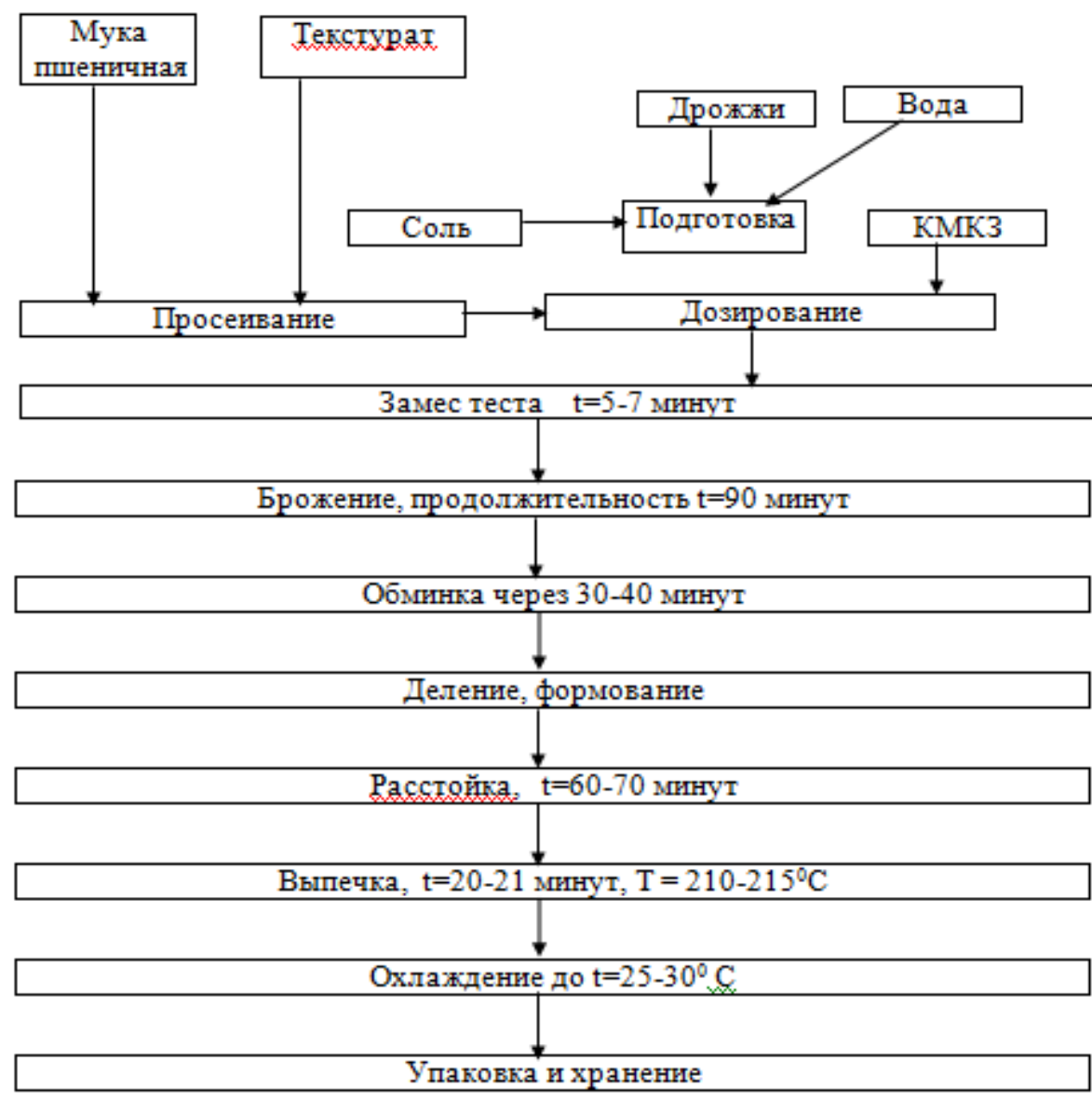

Puс. 1. Технологическая блок-схема производства булки русской круглой

Одним из значимых показателей в производстве булочных изделий, позволяющих оценить качество сырья, полуфабрикатов и готовой продукции, является число падения (ЧП) и водопоглотительная способность.

Если число падения ниже 160 с, то такое тесто обладает высокой автолитической активностью, что приводит к липкому, темному мякишу с неравномерной пористостью. Если ЧП муки свыше 400 с, в тесте протекает амилолиз крахмала, что приводит к замедлению процесса брожения и низкому удельному объему хлеба.

Из ранее проведенных исследований известно, что показатель числа падения текстурированных смесей составлял от 309 до 322 с. Такая смесь обладает высокими хлебопекарными свойствами и позволяет сократить продолжительность брожения теста, так как смеси с применением текстурированных продуктов обладают высокой сахаробразующей способностью [2]. Кроме того, в процессе выпечки булоч- 
ных изделий реакция меланоидинообразования протекает интенсивнее, что приводит к более интенсивному и равномерному цвету поверхности корочки, а также накоплению ароматобразующих веществ.
Полученные хлебобулочные изделия имели объем в диапазоне от 160 до $240 \mathrm{~cm}^{3}$ в зависимости от количества вносимой текстурированной муки.

\section{Показатели качества булки русской круглой с использованием текстурированной смеси}

\begin{tabular}{|c|c|c|c|}
\hline \multirow{2}{*}{$\begin{array}{l}\text { Показатель } \\
\text { качества }\end{array}$} & \multirow[t]{2}{*}{ Контроль } & \multicolumn{2}{|c|}{$\begin{array}{c}\text { Соотношение компонентов смеси: пшеничная мука в/с: } \\
\text { текстурированная мука }\end{array}$} \\
\hline & & \begin{tabular}{|l|l|}
$90: 10$ & $85: 15$ \\
\end{tabular} & \begin{tabular}{l|l|}
$80: 20$ & $75: 25$ \\
\end{tabular} \\
\hline \multicolumn{4}{|c|}{ Булка русская круглая с использованием текстурированной овсяной смеси } \\
\hline $\begin{array}{l}\text { Пропеченность, } \\
\text { промес, } \\
\text { пористость }\end{array}$ & \multicolumn{2}{|c|}{$\begin{array}{c}\text { Пропеченный, сухой на ощупь, } \\
\text { без комочков и следов непромеса. } \\
\text { Пористость равномерная, тонкостенная }\end{array}$} & $\begin{array}{l}\text { Хорошо пропеченные, с } \\
\text { вкраплениями, толсто- } \\
\text { стенная пористость, не- } \\
\text { равномерная }\end{array}$ \\
\hline Вкус и запах & $\begin{array}{c}\text { Ясно выраженный, без посто- } \\
\text { ронних привкусов, свойствен- } \\
\text { ные данному наименованию } \\
\text { изделий } \\
\end{array}$ & $\begin{array}{l}\text { Ясно выраженный, с } \\
\text { легким привкусом и } \\
\text { ароматом овса }\end{array}$ & $\begin{array}{l}\text { Ясно выраженный, со вку- } \\
\text { сом и ароматом овса }\end{array}$ \\
\hline $\begin{array}{l}\text { Поверхность и } \\
\text { цвет }\end{array}$ & \multicolumn{2}{|c|}{$\begin{array}{c}\text { Гладкая, не подгорелая, без вкраплений и трещин, цвет } \\
\text { равномерный золотисто-желтый }\end{array}$} & $\begin{array}{l}\text { Гладкая, с вкраплениями, } \\
\text { цвет более интенсивный }\end{array}$ \\
\hline Форма & \multicolumn{3}{|c|}{ Правильная, без деформаций } \\
\hline \multicolumn{4}{|c|}{ Булка русская круелая с использованием текстурированной ячменной смеси } \\
\hline $\begin{array}{l}\text { Пропеченность, } \\
\text { промес, } \\
\text { пористость }\end{array}$ & \multicolumn{2}{|c|}{$\begin{array}{c}\text { Пропеченный, сухой на ощупь, } \\
\text { без комочков и следов непромеса. Пористость равно- } \\
\text { мерная, тонкостенная }\end{array}$} & $\begin{array}{c}\text { Хорошо пропеченные, с } \\
\text { вкраплениями, толсто- } \\
\text { стенная пористость, не- } \\
\text { равномерная }\end{array}$ \\
\hline Вкус и запах & $\begin{array}{c}\text { Ясно выраженный, без посто- } \\
\text { ронних привкусов, свойствен- } \\
\text { ные данному наименованию } \\
\text { изделий }\end{array}$ & $\begin{array}{l}\text { Ясно выраженный, с } \\
\text { легким привкусом и } \\
\text { ароматом ячменя }\end{array}$ & $\begin{array}{l}\text { Ясно выраженный, со вку- } \\
\text { сом и ароматом ячменя }\end{array}$ \\
\hline $\begin{array}{l}\text { Поверхность и } \\
\text { цвет }\end{array}$ & \multicolumn{2}{|c|}{$\begin{array}{c}\text { Гладкая, не подгорелая, без вкраплений и трещин, цвет } \\
\text { равномерный золотисто-желтый }\end{array}$} & \multirow[t]{2}{*}{$\begin{array}{l}\text { Гладкая, с вкраплениями, } \\
\text { цвет более интенсивный }\end{array}$} \\
\hline Форма & & льная, без деформациі & \\
\hline
\end{tabular}

Из таблицы видно, что хлебобулочные изделия из мучных смесей, состоящих из муки пшеничной высшего сорта и текстурированного ячменя в соотношении: 95/5, 90/10, 85/15, и смесей из пшеничной муки высшего сорта и текстурированного овса в соотношении: 95/5, 90/10, 85/15 были пропеченными, сухими на ощупь, без комочков и следов непромеса. Пористость исследуемых образцов равномерная, тонкостенная. С увеличением доли текстурата в смесях до 20 и $25 \%$ (соотношение смеси 80/20, 75/25) хлебобулочные изделия были хорошо пропеченными, однако в них стали заметны вкрапления, пористость толстостенная, неравномерная.

Исходя из полученных органолептических показателей (вкус и аромат, структура и конси- стенция, форма, цвет и внешний вид), была проведена органолептическая оценка исследуемых образцов. Органолептический анализ пищевых продуктов проводится посредством дегустаций, осуществляемых с помощью органов чувств дегустатора без измерительных приборов. Показатели качества, определяемые с помощью зрения, - внешний вид, форма, цвет. Показатели качества, определяемые с помощью глубокого осязания, - консистенция, плотность, эластичность. Показатели качества, определяемые обонянием, - запах, аромат, «букет». Показатели качества, определяемые осязанием (в полости рта), - однородность, консистенция, сочность, нежность, вкусность (флевор), крошливость. 


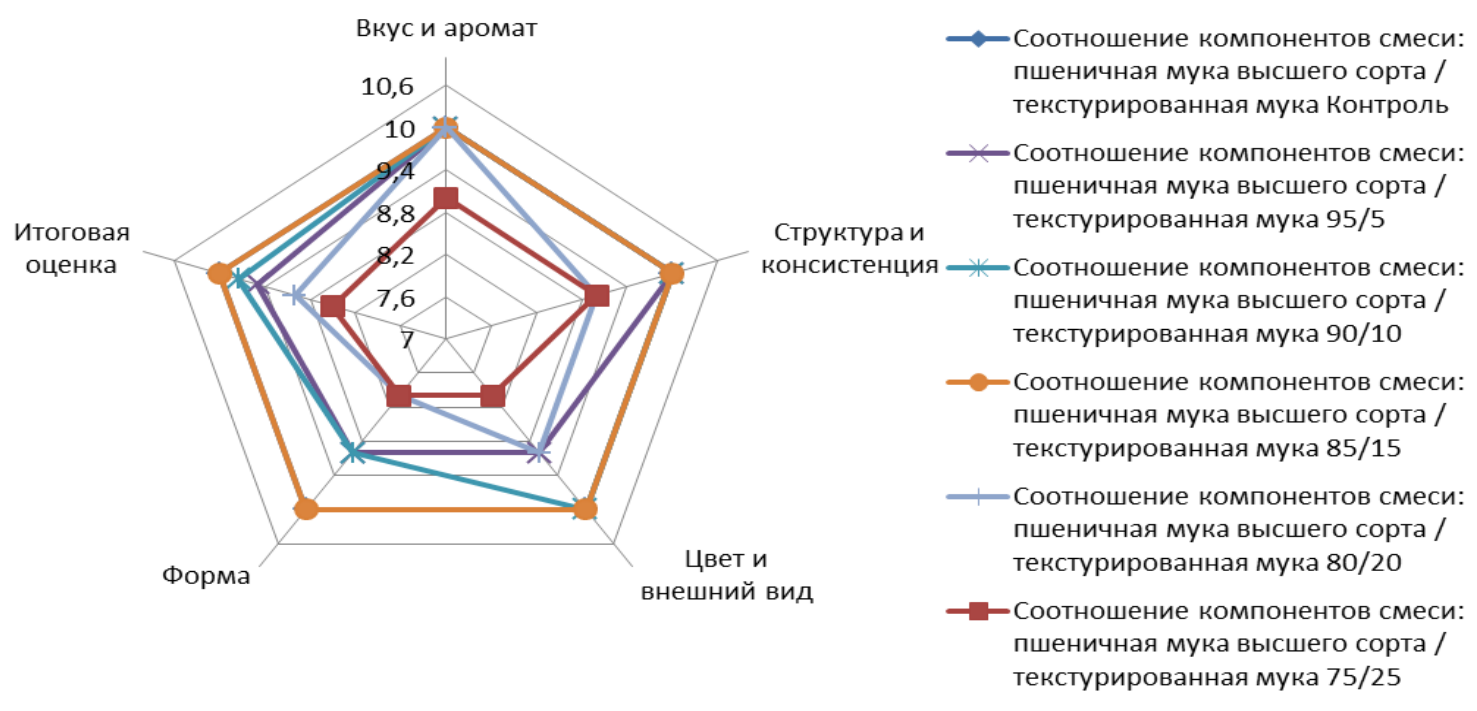

Puc. 2. Органолептическая оценка булки русской круглой из ячменной текстурированной смеси

Булка русская круглая, изготовленная с использованием смеси пшеничной муки и текстурата из ячменя и овса в соотношении $85 / 15$, имеет

наивысший балл органолептической оценки, а смесь с соотношением компонентных, составляющих 75/25, - наименьший балл (рис. 2, 3).

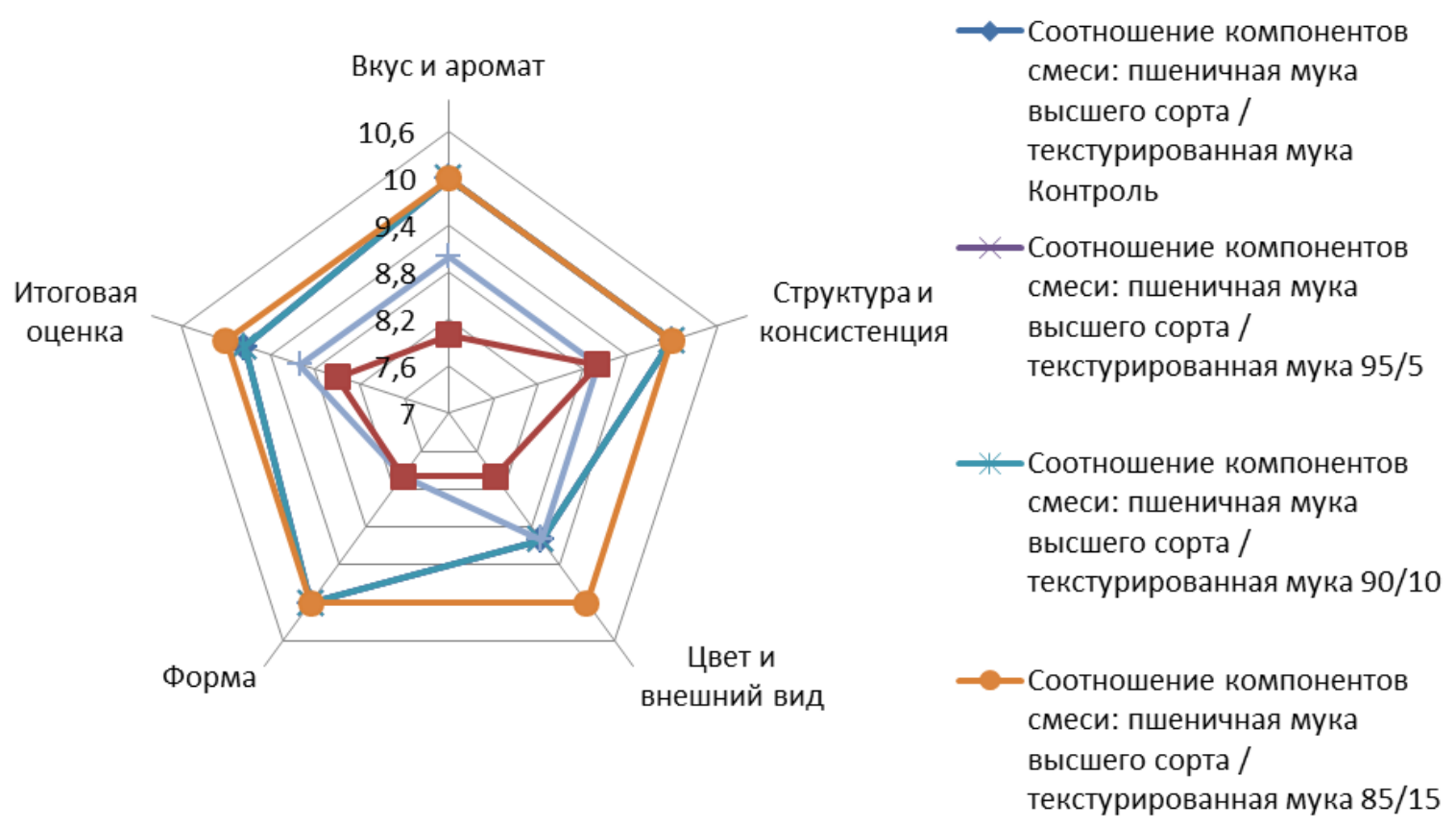

Puс. 3. Органолептическая оценка булки русской круглой из овсяной текстурированной смеси 
Показатель кислотности и влажности характеризуется качеством готового хлебобулочного изделия, его органолептическим и компонентным составом. По значению показателя кислотности можно судить о правильности ведения технологического процесса приготовления хлебобулочных изделий. Согласно стандартам ГОСТа для булки круглой русской, максимальная норма кислотности варьируется от 3 до 3,5 град, а влажности от 40 до $43 \%$.

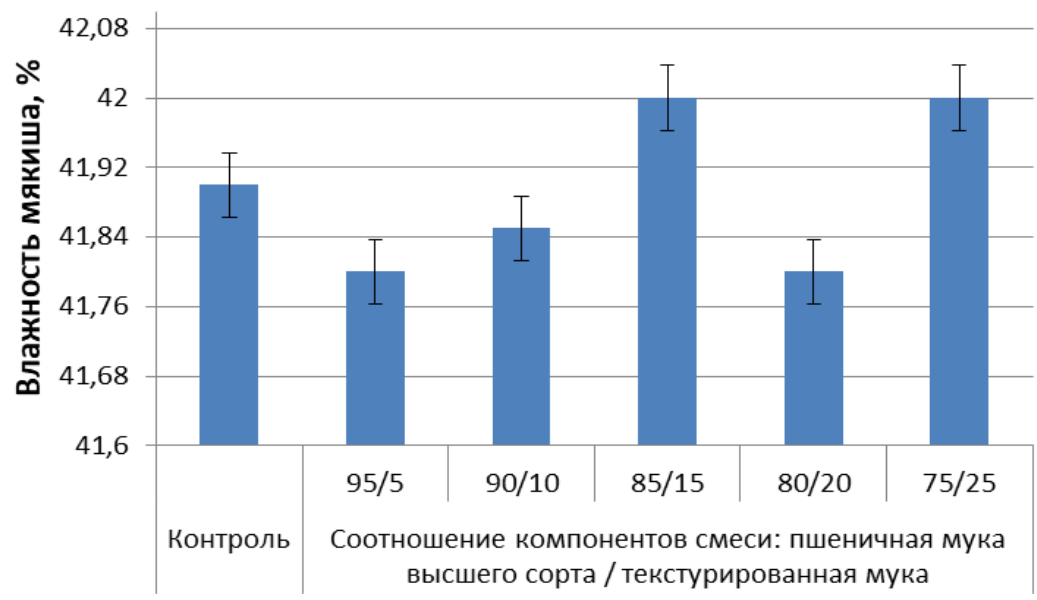

Puc. 4. Изменение влажности булки русской круглой с использованием текстурированной ячменной смеси

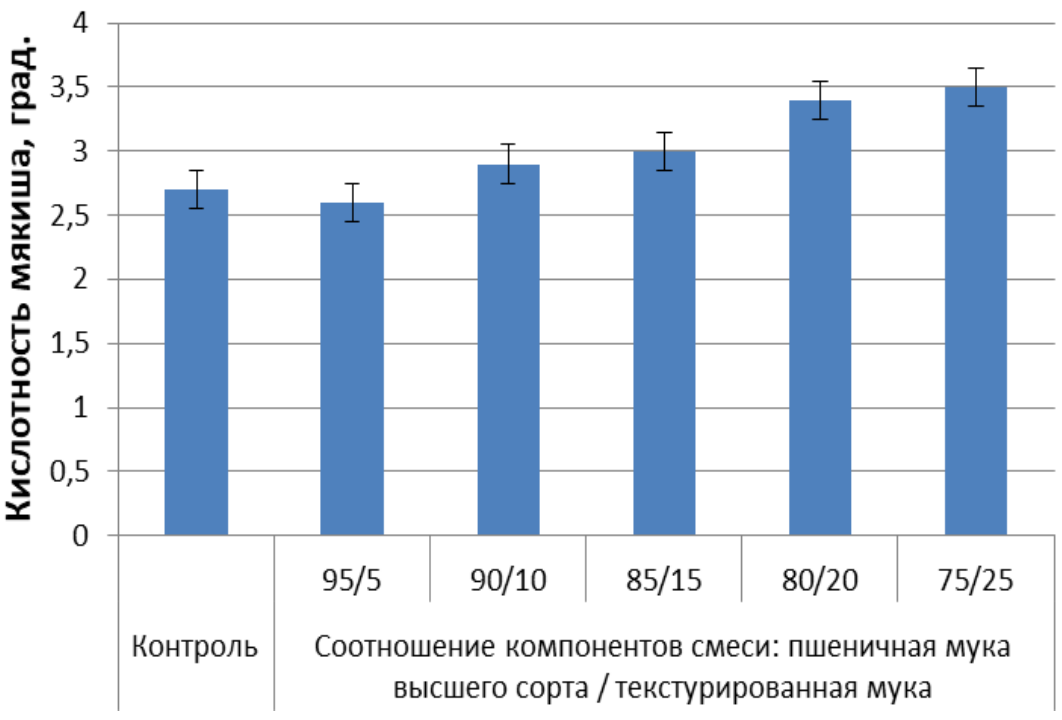

Pис. 5. Кислотность булки русской круглой с использованием текстурированной ячменной смеси

На рисунке 4 представлено изменение влажности булки русской круглой в зависимости от содержания количества текстурата ячменя в пшеничной муке. Наблюдается заметное увеличение влажности у образца № 3 (с соотношением компонентов 85/15) и № 5 (75/25), которое объясняется более высокой поглотительной способностью смеси пшеничной муки и ячменного текстурата в отличие от пшеничной муки.

На рисунке 5 прослеживается плавное увеличение кислотности у исследуемых образцов. Причем у образца № 5 с соотношением пшеничной муки и ячменного текстурата 75/25 показатель имеет крайнюю границу относительно стандартной нормы, что не желательно. 


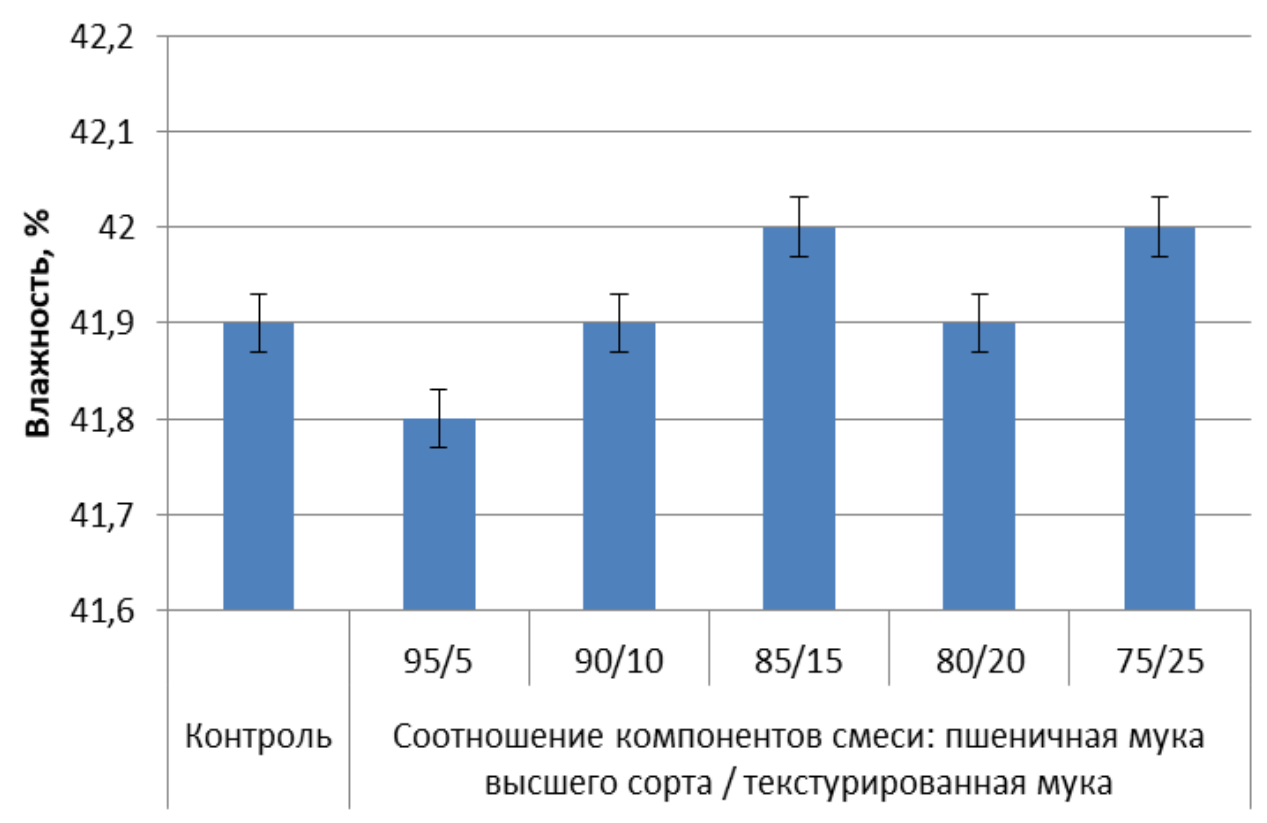

Pис. 6. Изменение влажности булки русской круәлой с использованием текстурированной овсяной смеси

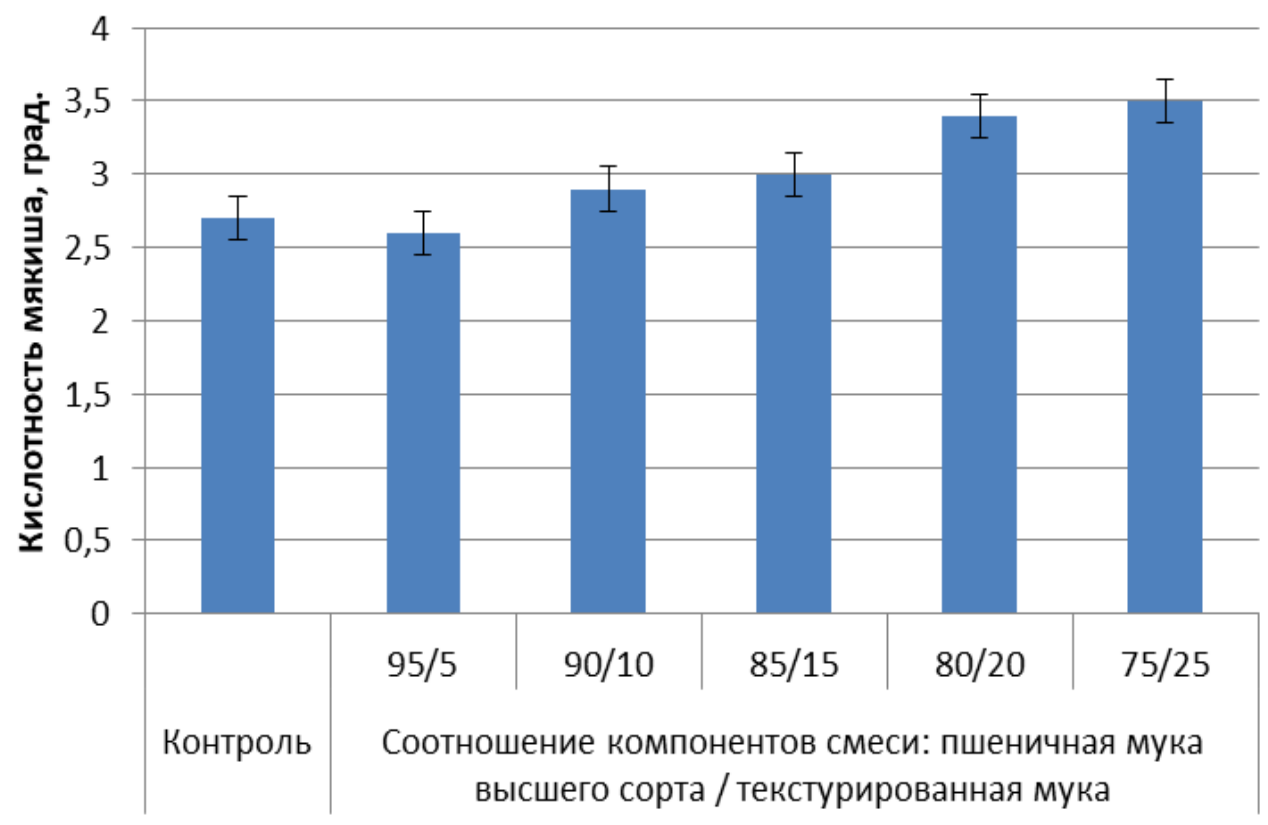

Puс. 7. Кислотность булки русской круглой с использованием текстурированной овсяной смеси

Аналогичная ситуация сложилась в исследовании влияния количества дозировки овсяного текстурата на качество булки русской круглой по физико-химическим показателям влажности и кислотности (рис. 6, 7).

Для комплексной и качественной оценки в данной работе булки русской круглой и образ- цов, изготовленных с различной дозировкой ячменных и овсяных текстуратов в пшеничной муке, обратимся еще к одному важному физикохимическому показателю ГОСТа - это пористость, которая должна быть не более 73 \%. 


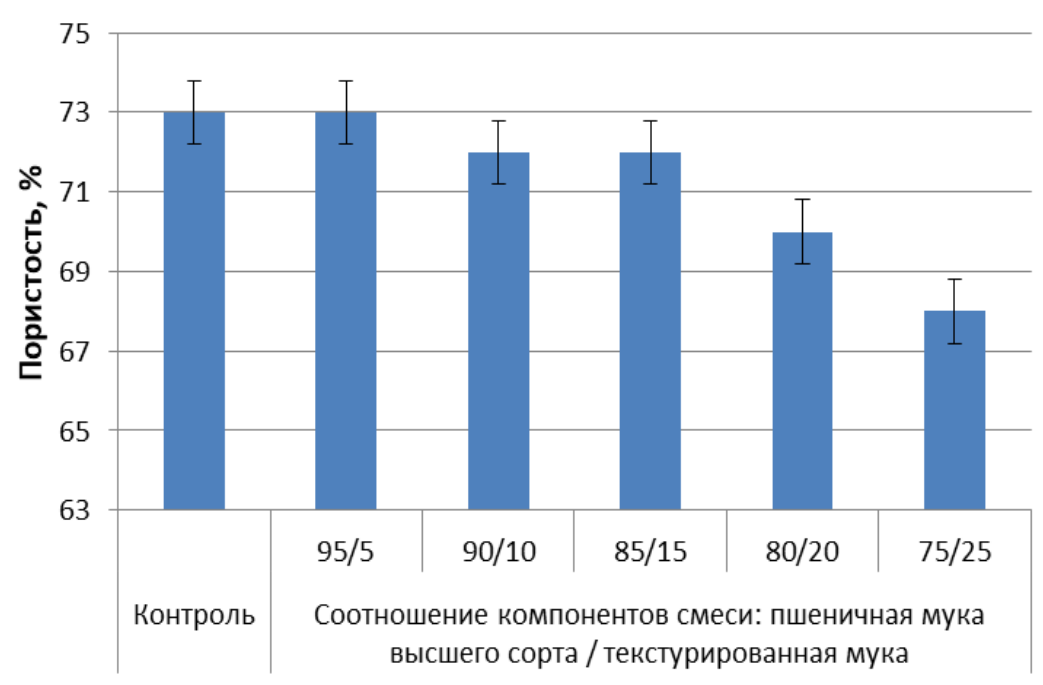

Puс. 8. Пористость булки русской круглой с использованием текстурированной овсяной смеси

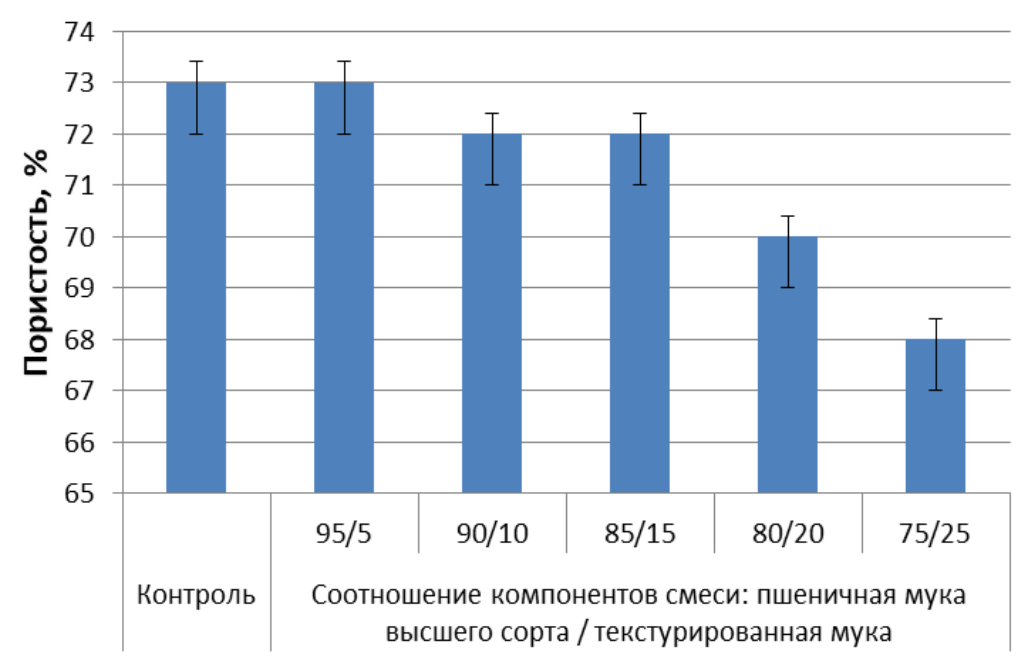

Puс. 9. Пористость булки русской круглой с использованием текстурированной ячменной смеси

Пористость хлебобулочных изделий с учетом ее структуры (величины пор, однородности, толщины стенок) характеризует его важное свойство - большую или меньшую усвояемость.

Из рисунков 8, 9 видно, что с увеличением содержания текстурата до 20-25\% значение пористости снижается во всех исследуемых образцах, но находится в рамках ГОСТа.

Полученные результаты по модификации компонентов рецептурного состава хлебобулочных изделий позволяют заключить, что использование смеси текстуратов из пшеничной муки ячменя и овса в процентном соотношении 85/15 в хлебопекарном производстве дает наилучший результат относительно контрольного образца из муки пшеничной высшего сорта.
В результате проведенных исследований по изучению модификации компонентов рецептурного состава выявлено, что лучшие результаты качественных характеристик булки русской круглой относительно контрольного образца из муки пшеничной высшего сорта показали изделия, произведенные по рецептуре с использованием смеси муки пшеничной высшего сорта и текстурата ячменя в соотношении 85/15 и смеси муки пшеничной высшего сорта и текстурата овса в соотношении 85/15.

\section{Выводы}

1. Различные дозировки текстуратов из зернового сырья в рецептурах булочных изделий влияют на качество готового продукта. По фризи- 
ко-химическим и органолептическим показателям лучший результат наблюдался у образцов с добавлением в рецептуру изделий текстурированного ячменя $15 \%$ или текстурированного овса $15 \%$.

2. При разработке рецептур булки русской круглой с использованием текстурированной смеси из зернового сырья рекомендуется применять следующие соотношения:

- мука пшеничная высшего сорта и текстурат ячменя: 85/15;

- мука пшеничная высшего сорта и текстурат овса: 85/15.

\section{Литература}

1. Шаповаленко Е.А., Бадмаева С.Э. Нацпроект «Экология» как средство по улучшению экологической обстановки города Красноярска // Современные проблемы землеустройства, кадастров и природообустройства: мат-лы нац. науч. конф. - Красноярск, 2019. - С. 313-316.

2. Янова М.А., Присухина Н.В., Горбунова Т.А. Влияние текстурированных продуктов из зернового сырья на состояние углеводноамилазного комплекса в мучных смесях для хлебобулочных изделий // Вестник КрасГАУ. - 2019. - № 11. - С. 127-132.

3. Гурских П.С., Янова М.А. Исследование мучной смеси из экструдатов злаковых культур для производства продуктов повышенной пищевой ценности // Пищевые технологии будущего: инновационные идеи, научный поиск, креативные решения: матлы науч.-практ. молодеж. конф. - М., 2019. - С. 87-91.

4. Казакова Е.С., Шабурова Г.В. Химический состав экструдированного овса // XXI век: итоги прошлого и проблемы настоящего плюс. - 2014. - № 6 (22). - С. 114-118.
5. Шмалько Н.А., Беликова А.В., Росляков Ю.Ф. Использование экструдированных продуктов в хлебопечении // Фундаментальные исследования. - 2007. № 7. - C. 90-92.

6. ГОСТ 27844-88. Изделия булочные. - М., 1988.

\section{Literatura}

1. Shapovalenko E.A., Badmaeva S.E. Nacproekt «Ekologiya» kak sredstvo po uluchsheniyu ekologicheskoj obstanovki goroda Krasnoyarska // Sovremennye problemy zemleustrojstva, kadastrov i prirodoobustrojstva: mat-ly nac. nauch. konf. Krasnoyarsk, 2019. - S. 313-316.

2. Yanova M.A., Prisuhina N.V., Gorbunova T.A. Vliyanie teksturirovannyh produktov iz zernovogo syr'ya na sostoyanie uglevodnoamilaznogo kompleksa $v$ muchnyh smesyah dlya hlebobulochnyh izdelij // Vestnik KrasGAU. - 2019. - № 11. - S. 127-132.

3. Gurskih P.S., Yanova M.A. Issledovanie muchnoj smesi iz ekstrudatov zlakovyh kul'tur dlya proizvodstva produktov povyshennoj pishchevoj cennosti // Pishchevye tekhnologii budushchego: innovacionnye idei, nauchnyj poisk, kreativnye resheniya: mat-ly nauch.prakt. molodezh. konf. - M., 2019. - S. 87-91.

4. Kazakova E.S., SHaburova G.V. Himicheskij sostav ekstrudirovannogo ovsa // XXI vek: itogi proshlogo i problemy nastoyashchego plyus. 2014. - № 6 (22). - S. 114-118.

5. Shmal'ko N.A., Belikova A.V., Roslyakov Yu.F. Ispol'zovanie ekstrudirovannyh produktov $v$ hlebopechenii // Fundamental'nye issledovaniya. - 2007. - № 7. - S. 9092.GOST 27844-88. Izdeliya bulochnye. M.,1988.

6. GOST 27844-88. Izdelija bulochnye. - M., 1988. 